\title{
Transferability of microsatellite primers developed for stingless bees to four other species of the genus Melipona
}

\author{
M.V.C. Viana ${ }^{1}$, E.A. Miranda ${ }^{1}$, A.K. de Francisco ${ }^{1}$, C.A.L. Carvalho ${ }^{2}$ \\ and A.M. Waldschmidt ${ }^{1}$ \\ ${ }^{1}$ Departamento de Ciências Biológicas, \\ Universidade Estadual do Sudoeste da Bahia, Jequié, BA, Brasil \\ ${ }^{2}$ Núcleo de Estudo dos Insetos, Universidade Federal do Recôncavo da Bahia, \\ Cruz das Almas, BA, Brasil
}

Corresponding author: A.K. de Francisco

E-mail: karinabrotas@yahoo.com.br

Genet. Mol. Res. 10 (4): 3942-3947 (2011)

Received August 1, 2011

Accepted September 1, 2011

Published November 22, 2011

DOI http://dx.doi.org/10.4238/2011.November.22.11

\begin{abstract}
Microsatellite markers are a useful tool for ecological monitoring of natural and managed populations. A technical limitation is the necessity for investment in the development of primers. Heterologous primers can provide an alternative to searching for new loci. In bees, these markers have been used in populational and intracolonial genetic analyses. The genus Melipona has the largest number of species among bee genera, about 70, occurring throughout the Neotropical region. However, only five species of the genus Melipona have specific microsatellite markers. Given the great diversity of this genus, this number is not representative. We analyzed the transferability of 49 microsatellite loci to four other species of the genus Melipona (M. scutellaris, M. mondury, M. mandacaia, and M. quadrifasciata). Four individuals of each species, from different localities, were used in amplification tests. Primer pairs described for five Melipona species and for Trigona carbonaria were tested. Among the 49 loci,
\end{abstract}


22 gave amplification products for all four species, while three gave nonspecific bands and five showed no amplification products. The remaining loci varied in the pattern of amplification, according to the species examined. The number of alleles ranged from 1 to 6 . The results demonstrate the possibility of using these heterologous markers in other Melipona species, increasing the number of loci that can be analyzed and contributing to further genetic analyses of intra- and intercolonial structure, which is required for conservation measure planning, genetic improvement and resolution of taxonomic problems.

Key words: Microsatellite; Transferability; Bees; Melipona; Conservation

\section{INTRODUCTION}

Microsatellites are codominant molecular markers based on simple repeated and frequent sequences common in eukaryotic genomes. Each microsatellite locus is highly variable, multiallelic and has high information content (Ferreira and Grattapaglia, 1998). These markers are a useful tool for ecological monitoring of natural populations, for developing stock populations and for genetic improvement (Bech et al., 2010). The limitation of the technique is the investment required for the development of primers. The use of primers developed for related species, i.e., transferability, can provide an alternative for the development of new markers (Patel et al., 2010). Various studies have demonstrated the possibility of using heterologous markers in plants (Gidugli et al., 2010, Chu et al., 2010), vertebrates (Bench et al., 2010; Mantellato et al., 2010) and invertebrates (Daly et al., 2002). In bees, these markers have been used in analyses of populations (Carvalho-Zilse et al., 2009) and for examining intracolonial genetic structure (Alves et al., 2009, 2010).

Bees are insects of the order Hymenoptera, whose major ecological role is pollination, which is necessary for the reproduction of plants and/or the reduction of inbreeding depression; in addition, their presence is associated with increased production and conservation of habitats (Michener, 2007). The Melipona genus has the largest number of species, about 70 (Moure et al., 2007), and can be found throughout the Neotropical region, from Mexico to Misiones, Argentina, with highest diversity in the Amazon basin (Camargo and Pedro, 1992, Silveira et al., 2002). Until now, microsatellite primers have only been described for five species of this genus: Melipona bicolor (Peters et al., 1998), Melipona rufiventris (Lopes et al., 2009), Melipona seminigra merrillae (Francini et al., 2009a), Melipona interrupta manaosensis (Francini et al., 2009b) and Melipona mondury (Lopes et al., 2010).

In order to increase the number of Melipona species to be studied using this methodology, we analyzed the transferability of 49 microsatellite loci to four other species of the genus Melipona.

\section{MATERIAL AND METHODS}

The species that we tested were Melipona (Michmelia) scutellaris, M. (Michmelia) mondury, M. (Melipona) mandacaia, and M. (Melipona) quadrifasciata. Four individuals of each species, from different locations, were used for amplification tests. Genomic DNA was isolated according to the protocol described by Waldschmidt et al. (1997). 
A total of 49 pairs of primers described for the species Melipona (Eomelipona) bicolor (Peters et al., 1998), Melipona (Michmelia) rufiventris (Lopes et al., 2009), Melipona (Michmelia) mondury (Lopes et al., 2010), Melipona (Melikerria) interrupta manaosensis (Franciniet al., 2009b), Melipona (Michmelia) seminigra merrillae (Francini et al., 2009a) and Trigona carbonaria (Green et al., 2001) were tested (Table 1).

The standardized $10 \mu \mathrm{L}$ reaction mixture consisted of $0.1 \mathrm{mM}$ of each deoxyribonucleoside triphosphate (dATP, dNTP, dGTP, dTTP), $0.4 \mathrm{mM}$ of each primer, $1.5 \mathrm{mM} \mathrm{MgCl} 2,0.5 \mathrm{U}$ Taq polymerase in $1 \mathrm{X}$ buffer and $20 \mathrm{ng}$ total genomic DNA. The mixture was incubated in an ATC201 model thermal cycler (NyxTechnik). The amplification program included an initial step at $94^{\circ} \mathrm{C}$, for $3 \mathrm{~min}, 40$ cycles with a first step at $92^{\circ} \mathrm{C}$ (denaturation), for $30 \mathrm{~s}$, a second step with annealing temperature specific to each primer, for $1 \mathrm{~min}$, and a third step at $72^{\circ} \mathrm{C}$ (extension), for $30 \mathrm{~s}$; there was a final extension at $72^{\circ} \mathrm{C}$, for $5 \mathrm{~min}$.

The amplification products were subjected to electrophoresis on $8 \%$ nondenaturing polyacrylamide gel and visualized by staining with $0.2 \%$ silver nitrate. Results of amplifications were classified as amplified, when expected size bands were detected, and as not amplified, when there was no amplified PCR product, or unspecific, when there were bands of unexpected size (Gao et al., 2005).

\section{RESULTS}

Mbi28, Mbi32, Mbi33, Mbi215, Mbi218, Mbi232, Mbi233, Mbi254, Mbi259, Mbi305, Mbi522, Mru14, Mmo15, Mim05, Msm03, Msm04, Msm05, Tc1-20, Tc3-155, Tc3-302, Tc4214, and Tc4-287 loci were amplified in all of the species (45\% of all loci). The Mim11 locus was amplified along with nonspecific bands, while Mbi221, Mim01, Msm12, Msm13 and Tc3-349 loci gave no amplification products (10\% of total). The other loci varied in the pattern of amplification, according to the species analyzed. The number of alleles ranged from 1 to 6 .

The success and polymorphism rates in amplifications for each species were: Melipona mondury, 59 and 24\%; Melipona mandacaia, 65 and 37\%; Melipona quadrifasciata, 69 and 37\%.

Table 1 shows the results, including the number of alleles and original and standardized annealing temperatures.

\section{DISCUSSION}

Due to the low number of specific primers developed for stingless bees so far, heterologous primers have been used in population studies, and in studies of mating and genetic structure in stingless bees. Carvalho-Zilse and Kerr (2006) tested 10 heterologous microsatellite primers, designed for Melipona bicolor and Apis mellifera, for population studies in Melipona scutellaris. Only the primers designed for M. bicolor were successful. With the purpose of studying the genetic variation of $M$. scutellaris colonies that were founded by only two colonies and multiplied for a period of 10 years in an apiary outside the natural area of occurrence of the species, Alves et al. (2010) used three microsatellite markers designed for Melipona bicolor and Scaptotrigona postica. In the state of Minas Gerais, Tavares et al. (2007) distinguished populations of Melipona rufiventris: Melipona mondury, which occurs in the Atlantic Forest, and M. rufiventris, which occurs in the Cerrado, through the use of microsatellite markers designed for Melipona bicolor, isozymes and RAPDs; they suggested 
Table 1. Amplification results (number of bands in bold) and PCR parameters in the testing of 49 heterologous microsatellite loci on four Melipona species.

\begin{tabular}{|c|c|c|c|c|c|}
\hline Loci & $\mathrm{Ta}\left({ }^{\circ} \mathrm{C}\right)$ & M. scutellaris (A) & M. mondury (A) & M. mandacaia (A) & M. quadrifasciata (A) \\
\hline Mbi11 & 55 & 1 & n.a. & 2 & 2 \\
\hline Mbi28 & 57.5 & 2 & 3 & 1 & 1 \\
\hline Mbi32 & 57.5 & $1\left[60^{\circ} \mathrm{C}^{*}\right]$ & 1 & 2 & 3 \\
\hline Mbi33 & 60 & $1\left[57.5^{\circ} \mathrm{C}\right]$ & $1\left[57.5^{\circ} \mathrm{C}\right]$ & $1\left[57.5^{\circ} \mathrm{C}\right]$ & 1 \\
\hline Mbi 88 & 57.5 & 1 & n.a. & 2 & 3 \\
\hline Mbi103 & 50 & n.a. & n.a. & 1 & 1 \\
\hline Mbi215 & 57.5 & $2\left[60^{\circ} \mathrm{C}\right]$ & 1 & $2\left[62.5^{\circ} \mathrm{C}\right]$ & 2 \\
\hline Mbi218 & 60 & 2 & $4\left[63^{\circ} \mathrm{C}^{* *}\right]$ & 3 & 2 \\
\hline Mbi219 & 57.5 & n.a. $\left[60^{\circ} \mathrm{C}\right]$ & n.a. $\left[60^{\circ} \mathrm{C}\right]$ & $2\left[60^{\circ} \mathrm{C}\right]$ & 1 \\
\hline Mbi221 & 60 & n.a. & n.a. & n.a. & n.a. \\
\hline Mbi232 & 50 & $5\left[53^{\circ} \mathrm{C}\right]$ & 2 & 2 & 4 \\
\hline Mbi233 & 57.5 & $5\left[53^{\circ} \mathrm{C}\right]$ & 3 & 5 & 4 \\
\hline Mbi254 & 55 & $4\left[53^{\circ} \mathrm{C}\right]$ & $6\left[64^{\circ} \mathrm{C}^{* *}\right]$ & 3 & 3 \\
\hline Mbi256 & 57.5 & $5\left[53^{\circ} \mathrm{C}\right]$ & in. & 2 & 2 \\
\hline Mbi259 & 57.5 & $1\left[53^{\circ} \mathrm{C}\right]$ & 1 & 1 & 1 \\
\hline Mbi278 & 60 & 1 & 2 & $1\left[65^{\circ} \mathrm{C}^{* * *}\right]$ & n.a. \\
\hline Mbi305 & 60 & 1 & 1 & 2 & 1 \\
\hline Mbi522 & 60 & 1 & 1 & 2 & 1 \\
\hline MRU 03 & 63 & $2\left[57^{\circ} \mathrm{C}\right]$ & $1\left[53^{\circ} \mathrm{C}\right]$ & in. $\left[53^{\circ} \mathrm{C}\right]$ & 3 \\
\hline MRU 14 & 62.5 & $2\left[58^{\circ} \mathrm{C}\right]$ & $2\left[60^{\circ} \mathrm{C}\right]$ & $3\left[60^{\circ} \mathrm{C}\right]$ & 3 \\
\hline MMO 08 & 59 & $1\left[58^{\circ} \mathrm{C}\right]$ & - & n.a. & n.a. \\
\hline MMO 15 & 54 & 2 & - & 1 & 1 \\
\hline MMO 21 & 57 & $1\left[56^{\circ} \mathrm{C}\right]$ & - & in. $\left[56^{\circ} \mathrm{C}\right]$ & in. \\
\hline MMO 22 & 61,5 & $4\left[59^{\circ} \mathrm{C}\right]$ & - & in. $\left[59^{\circ} \mathrm{C}\right]$ & in. \\
\hline MMO 24 & 52 & 1 & - & n.a. & n.a. \\
\hline MIM 01 & t.d. [62-52] & n.a. $\left[54^{\circ} \mathrm{C}\right]$ & n.a. $\left[54^{\circ} \mathrm{C}\right]$ & n.a. $\left[54^{\circ} \mathrm{C}\right]$ & n.a. $\left[54^{\circ} \mathrm{C}\right]$ \\
\hline MIM 05 & t.d. $[62-52]$ & $1\left[54^{\circ} \mathrm{C}\right]$ & $1\left[54^{\circ} \mathrm{C}\right]$ & $2\left[54^{\circ} \mathrm{C}\right]$ & $2\left[54^{\circ} \mathrm{C}\right]$ \\
\hline MIM 07 & t.d. $[62-52]$ & n.a. $\left[54^{\circ} \mathrm{C}\right]$ & n.a. $\left[54^{\circ} \mathrm{C}\right]$ & n.a. $\left[54^{\circ} \mathrm{C}\right]$ & in. $\left[54^{\circ} \mathrm{C}\right]$ \\
\hline MIM 08 & t.d. $[62-52]$ & $2\left[54^{\circ} \mathrm{C}\right]$ & $1\left[54^{\circ} \mathrm{C}\right]$ & n.a. $\left[54^{\circ} \mathrm{C}\right]$ & n.a. $\left[54^{\circ} \mathrm{C}\right]$ \\
\hline MIM 09 & t.d. $[62-52]$ & n.a. $\left[54^{\circ} \mathrm{C}\right]$ & n.a. $\left[54^{\circ} \mathrm{C}\right]$ & n.a. $\left[54^{\circ} \mathrm{C}\right]$ & $1\left[54^{\circ} \mathrm{C}\right]$ \\
\hline MIM 11 & t.d. $[62-52]$ & in. $\left[54^{\circ} \mathrm{C}\right]$ & in. $\left[54^{\circ} \mathrm{C}\right]$ & in. $\left[54^{\circ} \mathrm{C}\right]$ & in. $\left[54^{\circ} \mathrm{C}\right]$ \\
\hline MIM 12 & t.d. $[62-52]$ & in. $\left[55^{\circ} \mathrm{C}\right]$ & in. $\left[55^{\circ} \mathrm{C}\right]$ & in. $\left[55^{\circ} \mathrm{C}\right]$ & $4\left[55^{\circ} \mathrm{C}\right]$ \\
\hline MSM02 & t.d. $[62-52]$ & n.a. $\left[60^{\circ} \mathrm{C}\right]$ & n.a. $\left[60^{\circ} \mathrm{C}\right]$ & n.a. $\left[60^{\circ} \mathrm{C}\right]$ & n.a. $\left[60^{\circ} \mathrm{C}\right]$ \\
\hline MSM03 & t.d. $[62-52]$ & $1\left[60^{\circ} \mathrm{C}\right]$ & $1\left[60^{\circ} \mathrm{C}\right]$ & $1\left[60^{\circ} \mathrm{C}\right]$ & $1\left[60^{\circ} \mathrm{C}\right]$ \\
\hline MSM04 & t.d. $[62-52]$ & $2\left[60^{\circ} \mathrm{C}\right]$ & $2\left[60^{\circ} \mathrm{C}\right]$ & $2\left[60^{\circ} \mathrm{C}\right]$ & $1\left[60^{\circ} \mathrm{C}\right]$ \\
\hline MSM05 & t.d. $[62-52]$ & $1\left[60^{\circ} \mathrm{C}\right]$ & $1\left[60^{\circ} \mathrm{C}\right]$ & $1\left[60^{\circ} \mathrm{C}\right]$ & $1\left[60^{\circ} \mathrm{C}\right]$ \\
\hline MSM07 & t.d. $[62-52]$ & $2\left[60^{\circ} \mathrm{C}\right]$ & n.a. $\left[60^{\circ} \mathrm{C}\right]$ & $1\left[60^{\circ} \mathrm{C}\right]$ & n.a. $\left[60^{\circ} \mathrm{C}\right]$ \\
\hline MSM08 & t.d. $[62-52]$ & in. $\left[60^{\circ} \mathrm{C}\right]$ & in. $\left[60^{\circ} \mathrm{C}\right]$ & in. $\left[60^{\circ} \mathrm{C}\right]$ & $2\left[62^{\circ} \mathrm{C}\right]$ \\
\hline MSM 09 & t.d. $[62-52]$ & $1\left[55^{\circ} \mathrm{C}\right]$ & $1\left[55^{\circ} \mathrm{C}\right]$ & $4\left[55^{\circ} \mathrm{C}\right]$ & in. $\left[55^{\circ} \mathrm{C}\right]$ \\
\hline MSM12 & t.d. [62-52] & n.a. $\left[59^{\circ} \mathrm{C}\right]$ & n.a. $\left[59^{\circ} \mathrm{C}\right]$ & n.a. $\left[59^{\circ} \mathrm{C}\right]$ & n.a. $\left[59^{\circ} \mathrm{C}\right]$ \\
\hline MSM13 & t.d. [62-52] & n.a. $\left[59^{\circ} \mathrm{C}\right]$ & n.a. $\left[59^{\circ} \mathrm{C}\right]$ & n.a. $\left[59^{\circ} \mathrm{C}\right]$ & n.a. $\left[59^{\circ} \mathrm{C}\right]$ \\
\hline Tc1-20 & 55 & 1 & 1 & 1 & 2 \\
\hline Tc3-155 & 58 & 1 & 1 & 1 & 2 \\
\hline Tc3-302 & 56 & 2 & 2 & 2 & 3 \\
\hline Тc4-63 & 58 & 1 & n.a. & 1 & 1 \\
\hline Tc4-214 & 55 & 1 & 2 & 1 & 1 \\
\hline Tc4-287 & 58 & 2 & 1 & 2 & 4 \\
\hline Tc4-349 & 55 & n.a. & n.a. & n.a. & n.a. \\
\hline Tc7-13 & 58 & n.a. & n.a. & 1 & n.a. \\
\hline
\end{tabular}

Ta - original annealing temperature, (A) - number of alleles; td - Touchdown; n.a. - not amplified; in. - unspecific bands; [] tested temperatures; *Carvalho-Zilse and Kerr 2006; **Lopes, 2004; ***Werneck, 2008.

that the two populations from the Cerrado - Brasilândia de Minas and Dom Bosco - belong to a new species. For analysis of multiple mating and kinship among worker bees, Takahashi and Nakamura (2003) used primers designed for Apis mellifera to amplify four microsatellite loci from two colonies of Apis laboriosa. Palmer et al. (2002) used microsatellite markers designed for A. mellifera, Scaptotrigonapostica, Melipona bicolor, and Trigona carbonaria 
in seven species of the genera Scaptotrigona, Trigona and Austrophlebeia from Mexico and Australia for evaluation of multiple mating and multiple maternity of male Australian bees. Alves et al. (2009) assessed the maternity of males produced in colonies of M. scutellaris by means of three microsatellite primers designed for M. bicolor and S. postica.

As demonstrated by Carvalho-Zilse and Kerr (2006) with markers for A. mellifera, in M. scutellaris, and Lopes et al. (2009), with markers for M. rufiventris, in Partamona helleri, the success in the use of heterologous primers is lower in phylogenetically more distant species. In this study, results obtained regarding the four species of the genus Melipona (Melipona and Michmelia) using markers developed for other species of the same genus (subgenera Eomelipona, Michmelia and Melikerria) and for T. carbonaria show that, at least for species within the same tribe (Meliponini), evolutionary distance does not always prevent transfer of microsatellite markers (Table 2).

Table 2. Amplification success rate of loci for the bee species.
\begin{tabular}{lccccc}
\hline Loci & AR & $\begin{array}{c}\text { M. (Michmelia) } \\
\text { scutellaris }\end{array}$ & $\begin{array}{c}\text { M. (Michmelia) } \\
\text { mondury }\end{array}$ & $\begin{array}{c}\text { M. (Melipona) } \\
\text { mandacaia }\end{array}$ & $\begin{array}{c}\text { M. (Melipona) } \\
\text { uadrifasciata }\end{array}$ \\
\hline M. (Eomelipona) bicolor & 83.3 & 83.3 & 66.6 & 94.4 & 88.8 \\
M.(Michmelia) rufiventris & 87.5 & 100 & 100 & 50 & 100 \\
M. (Michmelia) mondury & 46.6 & 100 & - & 20 & 20 \\
M. (Melikerria) interrupta manaoensis & 28.5 & 28.5 & 28.5 & 5.28 & 42.85 \\
M. (Michmelia) seminigra merrilae & 50 & 55.5 & 44.4 & 87.5 & 75.5 \\
Trigona carbonaria & 75 & 75.5 & 62.5 & 5 \\
\hline
\end{tabular}

$A R=$ amplification rates (in \%) of primer pairs designed for each species.

According to Lopes et al. (2010), though heterologous markers can be used, the result must be carefully analyzed due to the presence of null alleles arising from mutations in the annealing sites. Only five species of the genus Melipona have specific microsatellite markers. This is not a representative number, considering that around 70 species have been described for this genus (Moure et al., 2007). In order to enable conservation studies, we need more information on the population genetics structure of these species.

Due to the large number of bee species and the high cost required to develop microsatellite markers, heterologous primers are a useful alternative. We were able to use heterologous markers in these Melipona species, increasing the number of loci that can be analyzed, allowing analysis of genetic diversity, intra and inter-colonial structure for conservation programs, as well as genetic improvement and problem solving in the classification of species.

\section{ACKNOWLEDGMENTS}

The authors acknowledge financial support from Programa Nacional de Pós-Doutorado/Coordenação de Aperfeiçoamento de Pessoal de Nível Superior (PNPD/CAPES), Fundação de Amparo à Pesquisa do Estado da Bahia (FAPESB), Universidade Estadual do Sudoeste da Bahia (UESB) and Universidade Federal do Recôncavo Bahiano (UFRB).

\section{REFERENCES}

Alves DA, Imperatriz-Fonseca VL, Francoy TM, Santos-Filho PS, et al. (2009). The queen is dead-long live the workers: intraspecific parasitism by workers in the stingless bee Melipona scutellaris. Mol. Ecol. 18: 4102-4111. 
Alves DA, Menezes C, Imperatriz-Fonseca VL and Wenseleers T (2010). First discovery of a rare polygyne colony in the stingless bee Melipona quadrifasciata (Apidae, Meliponini). Apidologie 42: 211-213.

Bech N, Novoa C, Allienne JF and Boissier J (2010). Transferability of microsatellite markers among economically and ecologically important galliform birds. Genet. Mol. Res. 9: 1121-1129.

Camargo JMF and Pedro SRM (1992). Systematics, phylogeny and biogeography of the Meliponinae (Hymenoptera, Apidae): a mini-review. Apidologie 23: 509-522.

Carvalho-Zilse GA and Kerr WE (2006). Utilização de marcadores microssatélites paraestudos populacionais em Melipona scutellaris (Apidae, Meliponini). Magistra 18: 213-220.

Carvalho-Zilse GA, Costa-Pinto MF, Nunes-Silva CG and Kerr WE (2009). Does beekeeping reduce genetic variability in Melipona scutellaris (Apidae, Meliponini)? Genet. Mol. Res. 8: 758-765.

Chu HJ, Yan J, Hu Y, Wang HC, et al. (2010). Cross-species amplification of 92 microsatellites of Medicago truncatula. Mol. Ecol. Resour. 10: 150-155.

Daly D, Archer ME, Watts PC, Speed MP, et al. (2002). Polymorphic microsatellite loci for eusocial wasps (Hymenoptera: Vespidae). Mol. Ecol. Notes 2: 273-275.

Ferreira ME and Grattapaglia D (1998). Introdução ao Uso de Marcadores Moleculares em Análise Genética. 3rd edn. EMBRAPA-CENARGEN, Brasília.

Francini IB, Sforça DA, Sousa ACB, Campos T, et al. (2009a). Microsatellite loci for an endemic stingless bee Melipona seminigra merrillae (Apidae, Meliponini) from Amazon. Conserv. Genet. 1: 487-490.

Francini IB, Sousa ACB, Força DAS, Costa-Pinto MFF, et al. (2009b). Isolation and characterization of microsatellite loci in the stingless bee Melipona interrupta manaosensis (Apidae: Meliponini). Conserv. Genet. 2: 27-30.

Gao LZ, Zhang CH and Jia JZ (2005). Cross-species transferability of rice microsatellites in its wild relatives and the potential for conservation genetic studies. Genet. Resour. Crop Ev. 52: 931-940.

Green CL, Franck P and Oldroyd BP (2001). Characterization of microsatellite loci for Trigona carbonaria, a stingless bee endemic to Australia. Mol. Ecol. Notes 1: 89-92.

Guidugli MC, Accoroni KA, Mestriner MA, Contel EP, et al. (2010). Genetic characterization of 12 heterologous microsatellite markers for the giant tropical tree Cariniana legalis (Lecythidaceae). Genet. Mol. Biol. 33: 131-134.

Lopes DM, DA Silva FO, Fernandes Salomao TM, Campos LA, et al. (2009). Microsatellite loci for the stingless bee Melipona rufiventris (Hymenoptera: Apidae). Mol. Ecol. Resour. 9: 923-925.

Lopes DM, Silva FO, Salomão TMF, Campos LAO, et al. (2010). A scientific note on the characterization of microsatellite loci for Melipona mondury (Hymenoptera: Apidae). Apidologie 41: 138-140.

Mantellatto AM, Carnelossi EA and Duarte JM (2010). Transferability of microsatellite loci from exotic Cervidae to Brazilian brocket deer (Mazama spp, Mammalia: Cervidae). Genet. Mol. Res. 9: 277-282.

Michener CD (2007). The Bees of the World. 2nd edn. The Johns Hopkins University Press, Baltimore.

Moure JS, Urban D and Melo GAR (2007). Catalogue of Bees (Hymenoptera, Apoidea) in the Neotropical Region. Socieda de Brasileira de Entomologia, Curitiba.

Palmer KA, Oldroyd BP, Quezada-Euan JJ, Paxton RJ, et al. (2002). Paternity frequency and maternity of males in some stingless bee species. Mol. Ecol. 11: 2107-2113.

Patel A, Das P, Barat A, Meher PK, et al. (2010). Utility of cross-species amplification of 34 rohu microsatellite loci in Labeobata, and their transferability in six other species of the cyprinidae family. Aquac. Res. 41: 590-593.

Peters JM, Queller DC, Imperatriz-Fonseca VL and Strassmann JE (1998). Microsatellite loci from the stingless bees. Mol. Ecol. 7: 783-792.

Silveira FA, Melo GAR and Almeida EAB (2002). Abelhas Brasileiras: Sistemática e Identificação. $1^{a}$ ed. Fundação Araucária, Belo Horizonte.

Takahashi JI and Nakamura J (2003). A scientific note on levels of polyandry of 2 queens of the Himalayan giant honeybee, Apis laboriosa. Apidologie 34: 191-192.

Tavares MG, Dias LAS, Borges AA, Lopes DM, et al. (2007). Genetic divergence between populations of the stingless bee uruçu amarela (Melipona rufiventris group, Hymenoptera, Meliponini): Is there a new Melipona species in the Brazilian state of Minas Gerais? Genet. Mol. Biol. 30: 667-675.

Waldschmidt AM, Salomão TMF, Barros EG and Campos LAO (1997). Extraction of genomic DNA from Melipona quadrifasciata (Hymenoptera: Apidae, Meliponinae). Braz. J. Genet. 20: 421-423. 